\title{
EVALUATING THE COOLING EFFECT AND THERMAL COMFORT OF SMALL URBAN GREEN SPACES ON THE CITY PEOPLE: THE CASE OF PLANNED RESIDENTIAL AREA OF UTTARA, DHAKA
}

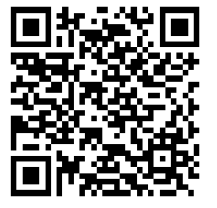

\author{
Saniya Tabassum Jhumur ${ }^{*}{ }^{\circledR}$ (iD) \\ ${ }^{* 1}$ Assistant Professor, Department of Architecture, Stamford University, Bangladesh
}

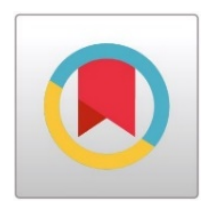

DOI: https://doi.org/10.29121/granthaalayah.v9.i1.2021.2978

Article Type: Research Article

Article Citation: Saniya Tabassum Jhumur. (2021). EVALUATING THE COOLING EFFECT AND THERMAL COMFORT OF SMALL URBAN GREEN SPACES ON THE CITY PEOPLE: THE CASE OF PLANNED RESIDENTIAL AREA OF UTTARA, DHAKA. International Journal of Research -GRANTHAALAYAH, 9(1), 99-111.

https://doi.org/10.29121/granthaa layah.v9.i1.2021.2978

Received Date: 01 January 2021

Accepted Date: 29 January 2021

Keywords:

Cooling Effect

Air Temperature

Comfort

Urban Green Spaces

Parks

Planned Residential Area

\section{ABSTRACT}

Urban Green spaces explore innovative approaches to increase the quality of urban settings, enhance livability and promote sustainable lifestyles. They provide environmental benefits through their effects on negating urban heat, increase comfort and the cooling impact of surrounding area. Therefore, it is very important to understand the mechanisms by which these benefits accrue. There is, thus, a need for proper planning of urban greenery to increase the benefits sought with the needs of the community and the functionality that the urban green space will serve. In Dhaka the overall situation of urban greenery and Park greenery is in a very poor state. In this research three small parks in the planned residential area of Uttara have been selected to find out their cooling effect and the level of comfort they exert on community people. Simulation studies were also done, to check the environmental performances of the Parks and on their surroundings. The analysis identifies that these Parks have an impact, the intensity of which depends on the type and quality of its vegetation, its design parameters, connectivity and of course on surrounding urban morphology. Thus, the paper offers a planning for urban park design for planned areas of Dhaka city.

\section{INTRODUCTION}

The urban green is an urbanistic instrument which is one of the most important aspects of livable communities. If appropriately planned and integrated into urban design, green spaces develop its own microclimate and thus it can contribute to the comfort of citizens and balance between natural and man-made environment. These spaces in the city act like its lungs, besides being used as active recreational and leisure areas for its citizens. They play a critical role in supporting the ecological and environmental system and social cohesion in urban life. Urban green spaces can act as 'Park Cool Islands' by cooling air [fig 1]and provide relief from the "Heat Island Effect" caused by the heat-trapping quality of asphalt, concrete and building materials. They help to improve the physical climate by increasing humidity, lowering temperatures and introduce more pleasant odors to the city; capture dust and gases

(C) 2021 The Author(s). This is an open access article distributed under the terms of the Creative Commons Attribution License, which permits unrestricted use, distribution, and reproduction in any medium, provided the original author and source are credited. 
from polluted air through deposition and capture by the foliage of plants and trees, and soil; and help break wind and intercept solar radiation, creating shadow and protecting places (Deelstra, T., Girardet, H., 2000) and thus increase the comfort level of green users and their surrounding community.

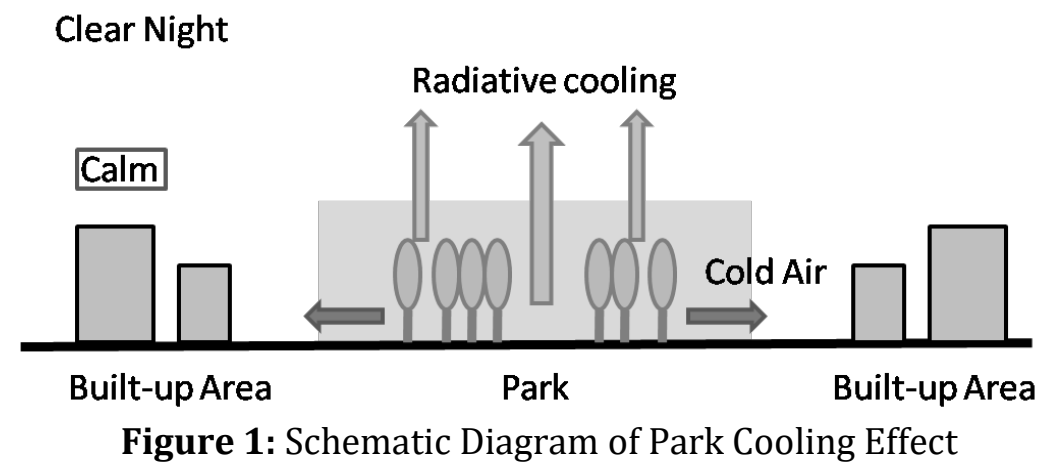

A study in Chicago determined that the air under a tree's canopy can be as much as $5-10^{\circ} \mathrm{F}$ cooler compared to full sun, with the underlying pavement up to $36^{\circ} \mathrm{F}$ cooler (Barton, S., 2008). In a recent study about the Heat Island in Singapore city (Yu and Hien, 2006), found that the cooling effects of city green areas are reflected not only in vegetated areas but also in the surrounding area, particularly at the leeward side of the green area. It is found an average temperature reduction of around $1^{\circ} \mathrm{C}$ for every $100 \mathrm{~m} 2$ of vegetation added to the Park surface (LA Fortezza, R., et.al. 2009). Therefore, it is widely professed that the urban green areas are key urban element which, due to their structure and multi functionality, can play an exemplary role in the vitality and for the quality of life, in several ways. In the dense urban areas, even small green spaces /parks (Green pockets) can contribute a lot to improve city life. The size of Small Urban Park is relative. According to National Recreation and Park Association Park Standards [1983] the size of a Small Urban Park is 2,500 square feet- 2 acres. From different standard it is found that, Small Park served almost $1 / 4$ mile service radius uninterrupted by non-residential roads or other physical barriers or within safe walking distance of residents of neighborhood. Clare Cooper Marcus identified in People Place that Mini- Park should serve the users within a four-block radius who can walk to it without crossing a major street [ fig 2].

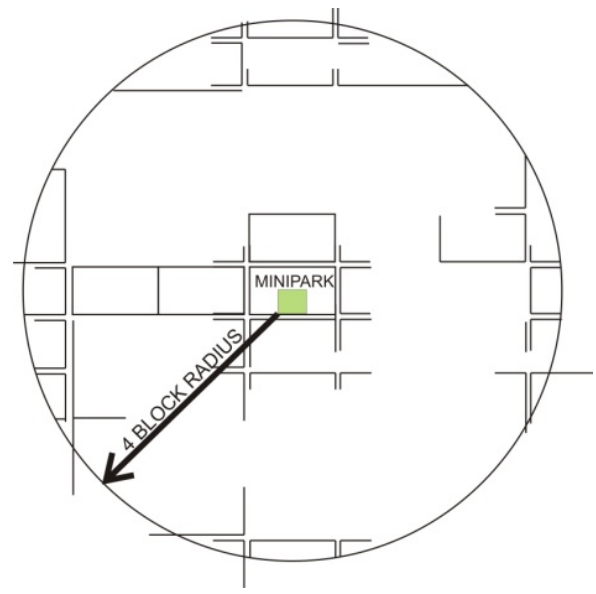

Figure 2: Service Radius of Small Park

The city of Dhaka [lies between longitudes $90^{\circ} 20 \mathrm{E}$ to $90^{\circ} 30 \mathrm{E}$ and latitudes $23^{\circ} 40 \mathrm{~N}$ to $23^{\circ} 55 \mathrm{~N}$ ] represents the south-central sub zone of Bangladesh. The city experiences a hot, wet and humid tropical climate, under the Köppen climate classification. On the other hand, Dhaka is one of the fastest growing megacities in the world and predicted to be one of the largest metropolises by 2025.This is particularly evident that rapid and unplanned urbanization, huge commercial developments, along with population pressure, the overall city environment gets deteriorated day by day. The Global Livability Index 2019 has placed Dhaka as the third least livable city in the world (DT, 2019). Today, the city fails to provide a green and healthy environment for its dwellers, whereas, it was once known for its 
serenity; beautiful Parks, clean roads and lush greenery. But it is essential to ensure good quality of life in urban areas, providing infrastructure, services and a healthy environment, with good livability. But in case of Dhaka, majority of the areas, old or new, are not properly planned and have little scope for creating any new green space or enhancing the existing ones. Therefore, this research focuses only on Small green spaces that still remain throughout the city

The study selected some small parks at planned residential areas of Dhaka and evaluate their cooling effect and impact on comfort level of residents. Thus, it tries to find out the potentiality of even small greens spaces for residential areas to enhance the quality of environment. Therefore, it is an approach to develop more of the small green spaces for densely built Dhaka city to ensure the livability.

\section{METHODOLOGY OF THE STUDY}

In the study Small parks within one acre in size have been selected as small green space. The approach of study was primarily through the field investigations on case study method, where the establishment of the design criteria of Small Urban green spaces or parks constitutes the initial stage of work along with the analysis of microclimatic conditions of Small Park and their surrounding environments. The second stage of work involves the study and analysis of comfort levels of various parks on their users and thus determining the overall contribution of Small Urban green spaces for livability.

Through a random survey, three parks at Planned Residential area of Uttara have been selected as case study. Field investigation was conducted in the month of March- April. This period is characterized by hot and dry weather. To find out the cooling effect of park in the park area and its impact on surroundings Air Temperature [deg C] and Relative Humidity [\%] and Illuminance Condition [lux] are measured. Theses data's have been measured at park center, its periphery and every 50' distance at each side up to 600' radius. To identify the environmental performances of these Park in their respective context comparative analysis of measured data has been done. ENVImet is a Computational Fluid Dynamics (CFD) - based micro-climate and local air quality model, developed by Prof. M. Bruse was designed to simulate the surface-plant-air interactions. ENVI-met simulations also have been applied to evaluate microclimatic impacts of these Small Parks, to understand their cooling effect.

After that comfort level of the users is measured for these parks. This is measured in two aspects; one in terms of Temperature Humidity Index (THI) and others from physical survey and questionnaire analysis. Temperature Humidity Index (THI) also known as Discomfort Index (DI) is one of the variants of Effective Temperature (ET), developed by Thom (1959). the following equation is used to measure THI

$\mathrm{THI}=0.8 \mathrm{Ta}+[\mathrm{RH} \times \mathrm{Ta}] / 500$

Where:

THI=Temperature Humidity Index

$\mathrm{Ta}=$ the air temperature $\left({ }^{\circ} \mathrm{C}\right)$

$\mathrm{RH}=$ the relative humidity $(\%)$

By empirically testing the THI values on human objects, the comfort limits are defined as:

$21 \leq \mathrm{THI} \leq 24=100 \%$ of the subjects felt comfortable

$24<\mathrm{THI} \leq 26=50 \%$ of the subjects felt comfortable

THI $>26=100 \%$ of the subjects felt uncomfortably hot

However, it must be mentioned that the above ranges were developed in the mid-latitudes Tropical residents are likely to tolerate higher levels of THI due to acclimatization as well as variations in food habitats and clothing (Emmanuel, 2005). Bedside these, a thorough analysis of spatial organization of the park, its vegetative condition and feedback from the users through questionnaire analysis have been done to identify the comfort level.

\section{RESULTS AND DISCUSSIONS}

\section{Study Area}

Uttara model town is a planned residential area at northern part of the city. Three Parks at sector 04,06 and 13, Uttara have been selected as study area to understand the Park impact on similar context. As we also know that Park 
cooling effect is better at planned area for regular grid iron road pattern. So, these three parks of at almost similar context but of different layout have been chosen for better comparison and analysis of park design and their impact.

\section{Park at Sector 04 Uttara}

The Park [area: 0.86Acre] is located at road no 05, sector 04, Uttara. The whole of the Park area is developed as a complex with a wide playfield at north and pond at west that help to promote community activism. The Park can also be viewed as unique landscapes that provide a connection between the residents and enhanced the attractiveness of neighborhood. It is also a walk way for all categories of men, women and children walkers. Over all area [90\%] of the park area is covered by green grass and Park periphery is shaded by various trees [only 10\%] of which Wide and Medium canopy trees like Jarul., Mehgani, Banyan, Shishu, Ipil-Ipil. Betel nut, Jackfruit, Raintree, Krishnachura cover 25\% [mostly at south east side of the park], small canopy trees $40 \%$, and shrub 35\% like Debdaru, Coconut, Krishnachura, Baganbilash, Hibiscus, Patabahar [at north west side].

\section{Park at Sector 06 Uttara}

The Park [area 0.28Acre] is located at road no 9, sector 6, Uttara. It is nice pocket Park for sector 6 neighborhood. The Park not only provides opportunities for daily socializing, but also sites for special events and celebrations for the neighborhood. The Park members are responsible for the maintenance and management of the Park. From questioner survey it is find out that the Park is the best place for the morning or exercise of the community people. It also helps people to relax and provide a good place to get together in a more public setting, or a place for single people to go if they just want to get out of their house or apartment. The park is mainly covered with trees [92\%] and only $8 \%$ of its area left for grass or other purposes. Most of the trees [75\%] are wide and medium canopy tree like Mehgani, Shegun, Mango, Black berry, Kathbadam, Neem, Bokul etc., 15\% occupies small canopy tree like Debdaru, Baganbilash at park periphery and 10\% shrub like Rose, Sunflower, Togor, hibiscus, Hasnahena, Patabahar etc.

\section{Park at Sector 13 Uttara}

The Park [1.02 Acre] is located in between of road no. 16 and 18 in sector 13, Uttara. Sector 13 is a newly developed neighborhood in Uttara. The Park is surrounded by roads and then buildings at three sides and a big play field at south side. The park has almost equal proportion of grass and tree cover area. It has almost 55\% grass covered open area with some play equipment and sitting. And the rest is covered by various trees. Among them, 35\% of the trees are wide and medium canopy [Banyan, Debdaru, Mango, Blackberry, Kathbadam, Neem, Bokul etc.], 35\% small canopy [Coconut, Palm] and 30\% shrub [Hibiscus, Dahlia, Sunflower, Patabahar etc.]. There is good play of light-shade in the Park area due to the various types of trees. Elderly and middle-aged people use this Park for exercise purposes and children come here to play in the evening. The Park in this new community thus helps in creating a sense of community and an enhanced environment for the neighborhood. Therefore, the social impact of the Park is also better.

\section{Data analysis}

To understand overall environmental performances selected Small Parks have been divided into three categories: These are

Category 1: Park at Uttara Sector 06 [ parks covered with mostly canopy trees]

Category 2: Park at Uttara Sector 13 [ parks covered with mixed canopy trees and grasses]

Category 3: Park at Uttara Sector 04 [ parks covered with mostly grasses and some canopy trees at periphery]

\section{Data Analysis from Physical Survey}

\section{Category 1: Park at Sector 06 Uttara}

Cooling Effect at Park Area: The Park is almost full of dense canopy trees which help to make the Park area cool and shaded all the time. Grass cannot grow sufficiently at the Park for the lack of sunlight. Air temperature remains almost same at park center and its four peripheries [27.4degC at center, $26.8 \mathrm{deg} \mathrm{C}$ at North, 27.6deg C at South, 27.2deg $\mathrm{C}$ at east and 26.9deg $\mathrm{C}$ at west] as almost all the area of the park is covered by trees. Beside these relative humidity [34.1\%] is higher at Park center than its periphery [29.5\%, 29.7\%, 30.3\% and $28.2 \%$ at North, 
South, East and west side accordingly]. Value of Illuminance [L] is observed very low at Park center [430X10 L] and also at periphery.

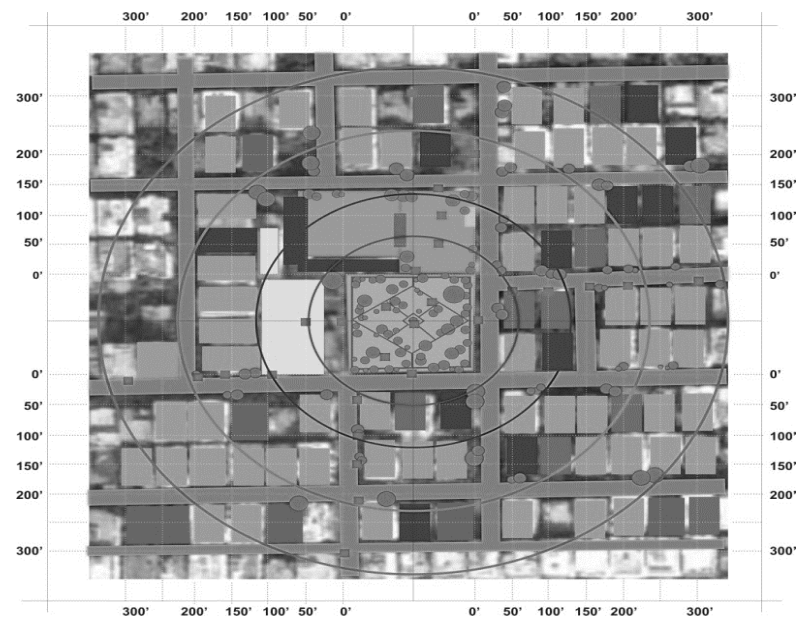

Figure 3: Surrounding context of the Park at Sector 6 Uttara and data measuring points

Cooling Effect at Park Area: The Park is almost full of dense canopy trees which help to make the Park area cool and shaded all the time. Grass cannot grow sufficiently at the Park for the lack of sunlight. Air temperature remains almost same at park center and its four peripheries [27.4degC at center, $26.8 \mathrm{deg} \mathrm{C}$ at North, 27.6deg C at South, $27.2 \mathrm{deg} C$ at east and $26.9 \mathrm{deg} C$ at west] as almost all the area of the park is covered by trees. Beside these relative humidity [34.1\%] is higher at Park center than its periphery [29.5\%, 29.7\%, 30.3\% and 28.2\% at North, South, East and west side accordingly]. Value of Illuminance [L] is observed very low at Park center [430X10 L] and also at periphery.

Cooling Effect at Surrounding Area: The surrounding area also remains cool because of the cooling effect of Park. In spite of that, in the northern side, temperature increases by $1.4 \mathrm{deg} C$, in the south, $1.5 \mathrm{deg} C$ in the east and $0.7 \mathrm{deg} \mathrm{C}$ up to $200 \mathrm{ft}$ distance from their periphery. It is noted that the Park radiates its most cooling effect in the three sides except in the west, which is block by buildings. Therefore, temperature increases $2.2 \mathrm{deg} C$ in the west [at 300'distant] from park periphery. Radius of cooling effect is observed up to 600ft radius for this park [depending on connectivity] where $450 \mathrm{ft}$ radius is an average.

Relative humidity decreases at surroundings and are lower than Park center but very similar to Park periphery because of the presence of some trees. Canopy trees at the periphery block sound in many cases and casts shadow. Illumination influxes also increase in the surrounding area than the Park area depending on the context. In the mornings and evenings, lots of people come to this Park for morning walk and exercise purposes. Although it remains close all day long, the Park influences positive social impact in the neighborhood.

\section{Category 2: Park at Sector 13 Uttara}

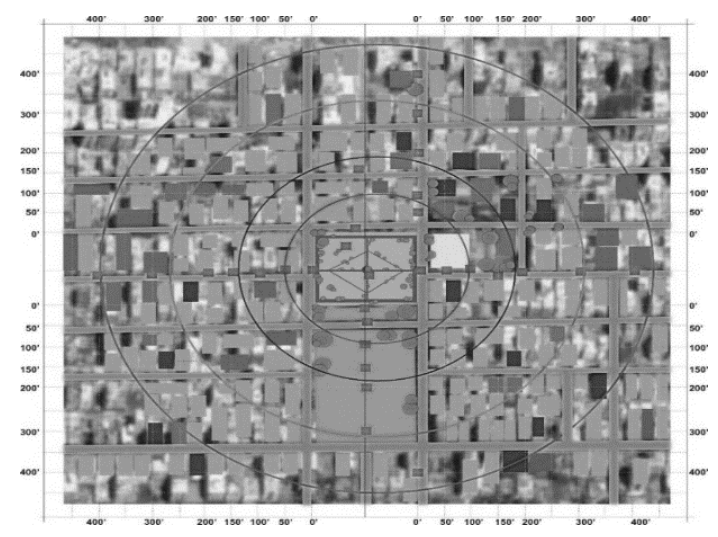

Figure 4: Surrounding context of the Park at Sector 4 Uttara and data measuring points 
Cooling Effect at Park Area: Canopy trees are located only at center and periphery of the Park area. The temperature [30.9 deg C] remains almost same at these areas. In this Park trees are almost equally distributed at the whole of the Park area. Therefore, value of air temperature at Park periphery is very close to the value of Park center.

Cooling Effect at Surrounding Area: At north side of the Park air temperature increase up to 0.7 deg $C$, at south $2.3 \mathrm{deg} \mathrm{C}$, at east side $1.6 \mathrm{deg} \mathrm{C}$ and $1.4 \mathrm{deg} \mathrm{C}$ at west side up to $200 \mathrm{ft}$ distance from their periphery [300 ft radius]. It is observed that difference of air temperature at Park surroundings and Park center is comparatively low than Parks of sector 6[park mostly covered with canopy trees]. Location of street at east and west side helps to radiate the cooling effect of Park. The south is open up to a long distance. But cooling effect of [wind flow from south] the Park are blocked by buildings of north side. Strong Park cooling effect is observed up to $300 \mathrm{ft}$ radius at surroundings [the temperature is almost same with temperature of park periphery] and it is maximum of $450 \mathrm{ft}$ depending on the context.

Besides these, in all measurement points of surroundings, relative humidity decreases than Park area. Illumination influx increase in the surrounding area than the Park but it is comparatively lower in the north-western side of the park because of some shaded streets and higher at playfield in the south.

\section{Category 3: Park at Sector 04 Uttara}

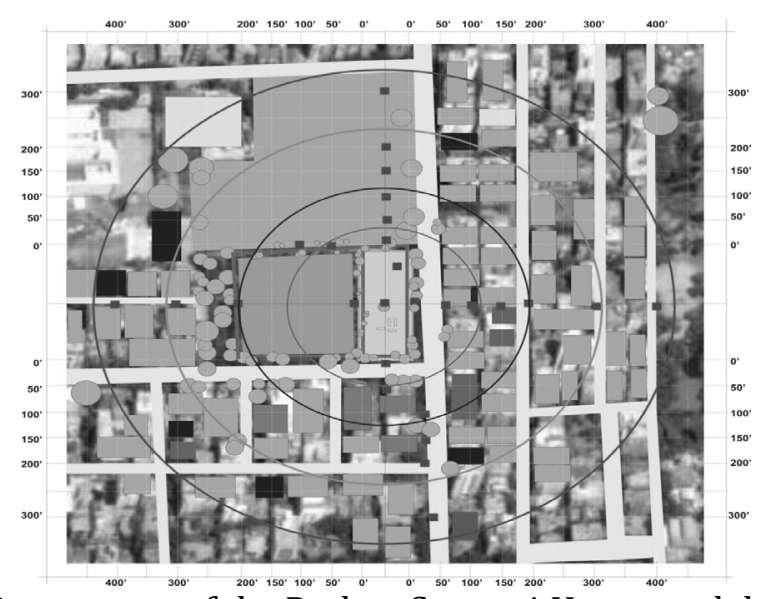

Figure 5: Surrounding context of the Park at Sector 4 Uttara and data measuring points

Cooling Effect Park Area: Measurement point at Park center is under the Park shelter. But In the other part Temperature [34.1deg C] and Illuminance level [1520X10 lux] and Relative Humidity [27.3\%] is high in the park area as it is mostly covered by grass and has an absence of canopy trees. Besides this, in the north and west, periphery illuminance level [1836X10 lux and 1740X10 lux] is also higher than in the south-eastern [430X10 and 510X10] side because of absence of canopy tree in the north-western side.

Cooling Effect at Surrounding Area: This Small Park is under a big open space complex i.e., play field at north, pond at west. Therefore, a mixed environmental impact found in its surroundings. Relative humidity is lower at surroundings than Park area. At north side of the Park area temperature increase up to 1.8 deg C [up to $200 \mathrm{ft}$ distance from the periphery]. The streets at south and east side of the Park help to radiate cooling effect. Therefore, in the south, temperature is $0.5 \mathrm{deg} C$ higher and in the east, $0.8 \mathrm{deg} \mathrm{C}$ higher from their respective periphery up to $200 \mathrm{ft}$ distance. Canopy trees at south east periphery helps to keep these sides cooler than other two sides. In the west side of the Park, there is a pond and temperature in that area varies in a different way. It is also to be noted that value of $\mathrm{T}$ is high at this Park. Therefore, overall temperature difference is low between Park area and its surroundings and the Park impact observed up to $200 \mathrm{ft}$ distance from Park periphery [within $300 \mathrm{ft}$ radius]. After that [from $300 \mathrm{ft}$ distance from Park periphery], the temperature is higher or almost similar to local temperature. Beside these, relative humidity and illuminance level decreases outside the park area. The Park complex has a good social impact on neighborhood. Various people enjoy the complex for various reasons mainly in the early mornings and evenings. The Park area with its surroundings attracts the users very much and it remains lively all day long. 


\section{Analysis from Envi-met Simulation}

To understand overall environmental performances of Small Parks, ENVI-met simulation [version 3.1.0] has been applied on three Parks in the three different categories. Maximum of $200 \mathrm{ft}$ distance from Park periphery has been selected to observe simulation effect. Following are the basic input parameters for simulation of this study.

Table 1: Basic Input Parameters for Simulation

\begin{tabular}{|c|c|}
\hline Location & Dhaka, Bangladesh, $23.24^{\circ} \mathrm{N}, 90.23^{\circ} \mathrm{E}$, \\
\hline Simulation day & 03.03 .2013 \\
\hline Simulation duration & From 8:00-2:00 (6h) \\
\hline Spatial resolution & 110x80x25 grids, grid size: $2 \times 2 \times 3 \mathrm{~m}$ \\
\hline Wind speed and direction & $2.9 \mathrm{~m} \mathrm{sec}-1,10 \mathrm{~m}$ ab. Ground from $225^{\circ}$ (south-west) \\
\hline Avg Relative Humidity in $2 \mathrm{~m}$ & $60.5 \%$ \\
\hline Initial temperature of atmosphere & $293 \mathrm{~K}$ \\
\hline Heat transmission & $\begin{array}{l}\text { Walls: } 1.7 \mathrm{~W} \mathrm{~m}-2 \mathrm{~K} \\
\text { Roofs: } 2.2 \mathrm{~W} \mathrm{~m}-2 \mathrm{~K}\end{array}$ \\
\hline Albedo & $\begin{array}{l}\text { Walls: } 0.3 \\
\text { Roofs: } 0.15\end{array}$ \\
\hline
\end{tabular}

Table 2: Simulation Analysis of Park at Uttara

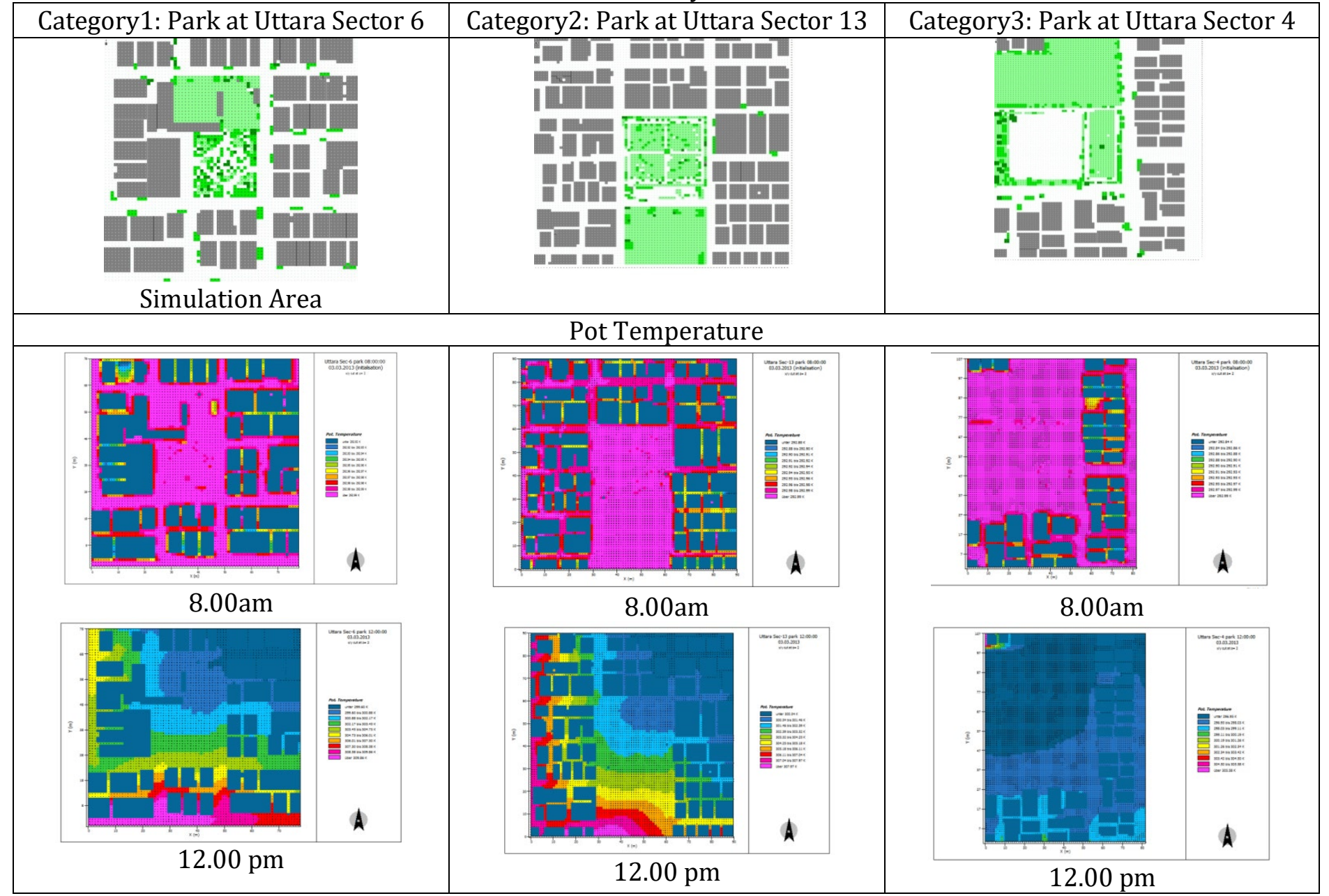




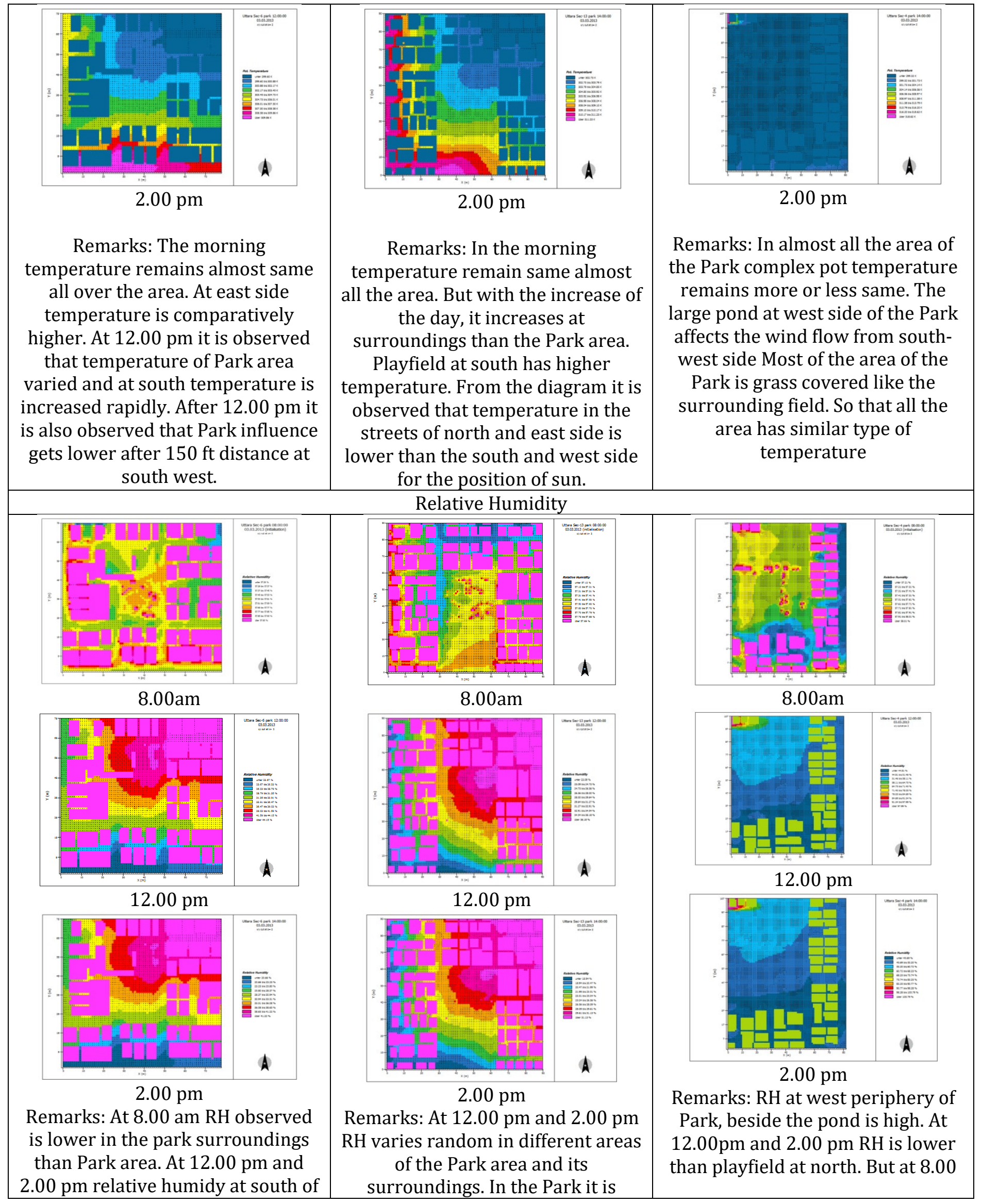




\begin{tabular}{|c|c|c|}
\hline $\begin{array}{l}\text { the Park is lower than northern } \\
\text { side [there is a green playfield at } \\
\text { north of the Park, where RH is } \\
\text { highest]. Location of some street } \\
\text { trees help to vary relative humidity } \\
\text { at Park surroundings. }\end{array}$ & $\begin{array}{l}\text { higher and gradually gets lower at } \\
\text { surroundings. At } 8.00 \text { pm RH is } \\
\text { highest at some points of Park, } \\
\text { which are under some canopy tree. } \\
\text { RH is higher at north east corner of } \\
\text { Park for canopy trees. }\end{array}$ & $\begin{array}{l}\text { am it is high at pond area and } \\
\text { playfield beside the pond. }\end{array}$ \\
\hline \multicolumn{3}{|c|}{ Direct Solar Radiation } \\
\hline 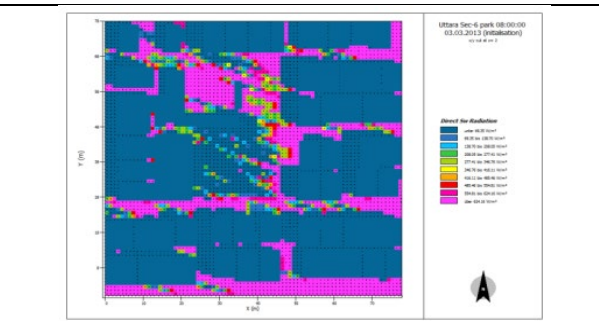 & 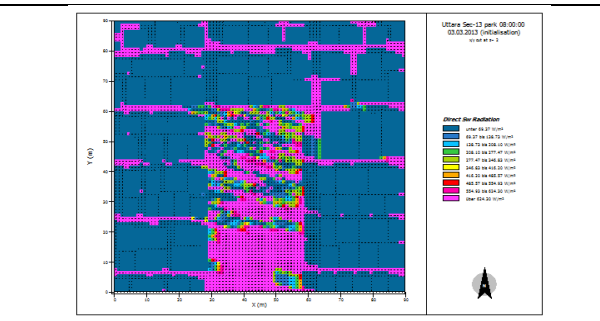 & $\underline{\underline{z}}$ \\
\hline $8.00 \mathrm{am}$ & $8.00 \mathrm{am}$ & 8.00am \\
\hline$\underline{\underline{n+2}}$ & 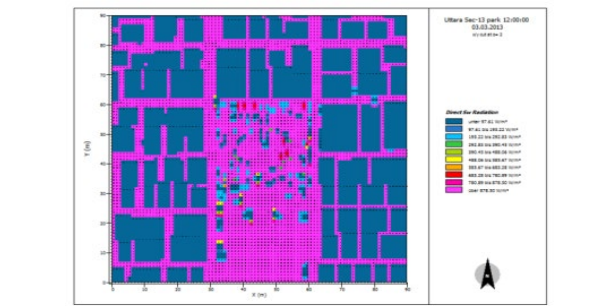 & 焉 \\
\hline $12.00 \mathrm{pm}$ & $12.00 \mathrm{pm}$ & $12.00 \mathrm{pm}$ \\
\hline$\underline{\underline{2}}$ & 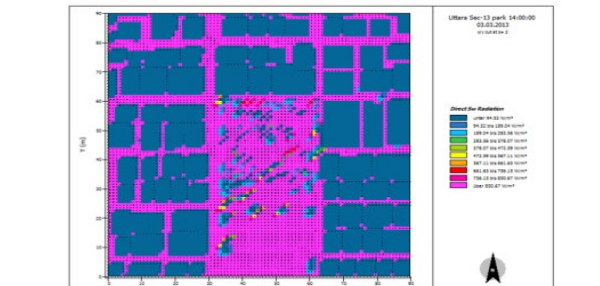 & 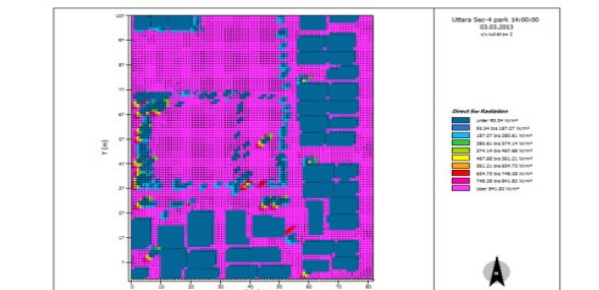 \\
\hline $2.00 \mathrm{pm}$ & $2.00 \mathrm{pm}$ & $2.00 \mathrm{pm}$ \\
\hline $\begin{array}{l}\text { Remarks: The Park is mostly } \\
\text { covered by the dense canopy trees. } \\
\text { These block the solar radiation to } \\
\text { reach near above ground level. } \\
\text { Therefore, the Park remains shaded } \\
\text { most of the time. }\end{array}$ & $\begin{array}{l}\text { Remarks: Values of direct solar } \\
\text { radiation varies at Park area, } \\
\text { because of the presence of different } \\
\text { types of trees at park area. }\end{array}$ & $\begin{array}{l}\text { Remarks: The periphery of the Park } \\
\text { has some canopy trees, under } \\
\text { which value of Direct Solar } \\
\text { Radiation is low. Otherwise, most of } \\
\text { the area of Park, playfield and pond } \\
\text { are exposed under direct sun. }\end{array}$ \\
\hline \multicolumn{3}{|c|}{ Result } \\
\hline $\begin{array}{l}\text { 1. The Park area remains cool than } \\
\text { surrounding. Strong cooling effct of } \\
\text { park is observed at surroundings } \\
\text { [temperature remains low than } \\
\text { other area] upto certain distance } \\
\text { 2. RH is high at Park area. Except } \\
\text { some roads with many trees, RH is } \\
\text { low at surroundings. } \\
\text { 3. The Park remains shaded all the } \\
\text { time. Direct Solar Radiation is high } \\
\text { at surroundings than Park area. }\end{array}$ & $\begin{array}{l}\text { 1. Temperature remains low at } \\
\text { Park area than the surrounding } \\
\text { area. An average effect depending } \\
\text { on the context is noticed. } \\
\text { 2. Relative Humidity is high at Park } \\
\text { area. } \\
\text { 3. RH is very high at grass cover } \\
\text { area beside the pond. After certain } \\
\text { [150 ft appx.] distance it started to } \\
\text { decrease. }\end{array}$ & $\begin{array}{l}\text { 1. Temperature remain same } \\
\text { almost all the of area and its } \\
\text { surroundings. Cooling effect is low } \\
\text { on its surroundings } \\
\text { 2. RH is very high at grass cover } \\
\text { area beside the pond. After certain } \\
\text { [150 ft appx.] distance it started to } \\
\text { decrease }\end{array}$ \\
\hline
\end{tabular}


Evaluating the Cooling Effect and Thermal Comfort of Small Urban Green Spaces on The City People: The Case of Planned Residential Area of Uttara, Dhaka

\begin{tabular}{|c|c|c|}
\hline & \multicolumn{2}{|c|}{$\begin{array}{c}\text { Solar radiation is high at most of } \\
\text { the Park area which is almost same } \\
\text { to the surrounding street. }\end{array}$} \\
\hline \multicolumn{2}{|c|}{ Remark } \\
\hline $\begin{array}{c}\text { Excellent environmental impact on } \\
\text { surrounding built environment }\end{array}$ & $\begin{array}{c}\text { Good environmental impact on } \\
\text { surrounding built environment }\end{array}$ & $\begin{array}{c}\text { Minimum environmental impact on } \\
\text { surrounding built environment }\end{array}$ \\
\hline
\end{tabular}

From cooling effect analysis [both physical survey and Envi-met analysis] it has been found that all the three parks have positive environmental impact. Temperature remains low in the park area than the surroundings. However, among the three cases, the park in sector 6 has the most trees [wide and medium canopy] and less open grass area. This park remains shaded all the time, temperature is low and have strong cooling effect on the surroundings. The park in Sector 13, have almost equal ratio of grass cover open space and shaded space with canopy trees. Here temperature is also lower than the surroundings and moderate cooling impact observed on its neighborhood. But spatial organization is different in the park at sector 4 . The park is mainly covered by grass and few canopy trees at periphery. This park is not suitable for hot humid climate of the city as temperature, humidity and radiation is found higher in park area and very minimum impact is found on its surroundings. But in early mornings and evenings, the park shows very positive impact, which is also observed on the surrounding.

From the analysis it is also found that spatial organization and planning of surrounding neighborhood is an important factor for the cooling impact of green spaces in its surrounds. Uttara is a planned residential area. Most of the parks have streets in two or three sides which help them to radiate the cooling effect on its surroundings. The cases where there are buildings beside the park, the cooling effect radiates minimum in those sides but the dwellers of those buildings are highly satisfied due to the park's cooling effect.

\section{Analysis of Comfort Level}

To evaluate Small Parks of Dhaka city THI equation has been used to know the comfort range of Park users and thus the performance of the Park. The recorded data at the center of the Park was applied into this equation, whose results have been analyzed below:

Table 3: THI Index and Comfort Analysis of the Studied Small Park

\begin{tabular}{|c|c|c|c|}
\hline Category & Park Name & THI [Park center] & Remarks \\
\hline 01 & Park at Uttara sector 6 & 24 & $100 \%$ of the subjects felt comfortable \\
\hline 02 & Park at Uttara sector 13 & 26 & $50 \%$ of the subjects felt comfortable \\
\hline 03 & Park at Uttara Sector 04 & 29 & $100 \%$ of the subjects felt uncomfortable \\
\hline
\end{tabular}

A questionnaire survey was also done among the park users at various times of the day and it has been found that, $70 \%$ of the users of Park in Uttara sector 6 verified that their experience was very comfortable and $20 \%$ comfortable. Most of the users mentioned that they can use the park at any time of the day. 25\% of the users of the Park at Uttara sector 13 feel that the park is very comfortable and 55\% feel comfortable. They can use it only in the morning and evening hours. And 20\% of the users of the Park in Uttara Sector 4 stated their experience was not at all comfortable. To $65 \%$, the environment is comfortable and to $20 \%$ it is very comfortable. They stated that it is used only in the morning and evening hours for walking and children's playing.

\section{Overall Findings}

At a glance it can be said all the three parks, even though they are very small in size, have a strong cooling effect on its surrounding neighborhood. In case of the Parks of category 01[Uttara Sector 6] temperature increases 2.6 deg C, for Parks of category 02[Uttara Sector 13] it increases 1.8deg C and for Parks of category 03[Uttara Sector 4] it increases $1.6 \mathrm{deg} C$ in the surrounding area. From the simulation analysis same thing has been observed. It has also been found that performance of the Park of category 02[Uttara Sector 13- park covered with mixed canopy trees and grasses] is comparatively better than the Parks of category 03[Uttara Sector 4- parks covered with mostly grasses and some canopy trees at periphery]. Performance of the parks of category 01[Uttara Sector 6- parks covered with mostly canopy trees] is best. Canopy trees of that Park create good shading. This situation helps to increase comfort 
during the bright sunny days. According to questionnaire survey and comfort calculation, performance of parks of category 01[Uttara Sector 6] is also better than others. Surrounding context like street layout and vehicular pressure, building layout, presence of street trees or any other green spaces, nearby water bodies also play an important role to radiate the cooling effect but within 300' radius it is strong in all case of all parks and in the case of parks with more canopy trees, cooling impact observed up to 600' radius. It is also observed from simulation analysis and physical survey that the road layout of park's surroundings helps to radiate cooling effect.

\section{CONCLUSIONS AND RECOMMENDATION}

In this research it is evident that urban green spaces, even very small in size, have a strong cooling effect and improve the comfort level of the users. And it is also observed that, their impacts are reflected not only in vegetated areas but also in the surrounding areas depending on the type and quality of its vegetation, its design quality and on the surrounding context. They help to build a sense of belonging of their community and effectively increase livability of the city. Canopy trees provide shading and increase comfort level, hence parks designed with mostly canopy trees are suitable for the city like Dhaka. Therefore, Proper arrangement of wide and small canopy tree and limited grass cover with combination of paved area [wide canopy trees at periphery, medium canopy trees beside internal walkway and small canopy tree, shrub and grass cover elsewhere] and selection of proper location for the park with proper connectivity will help to enhance its performance much more.

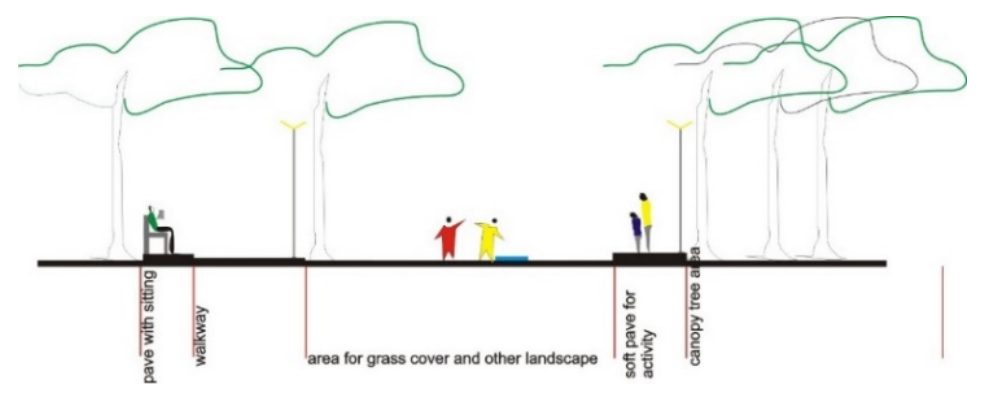

Figure 6: Distribution of Canopy Tree in Park Area

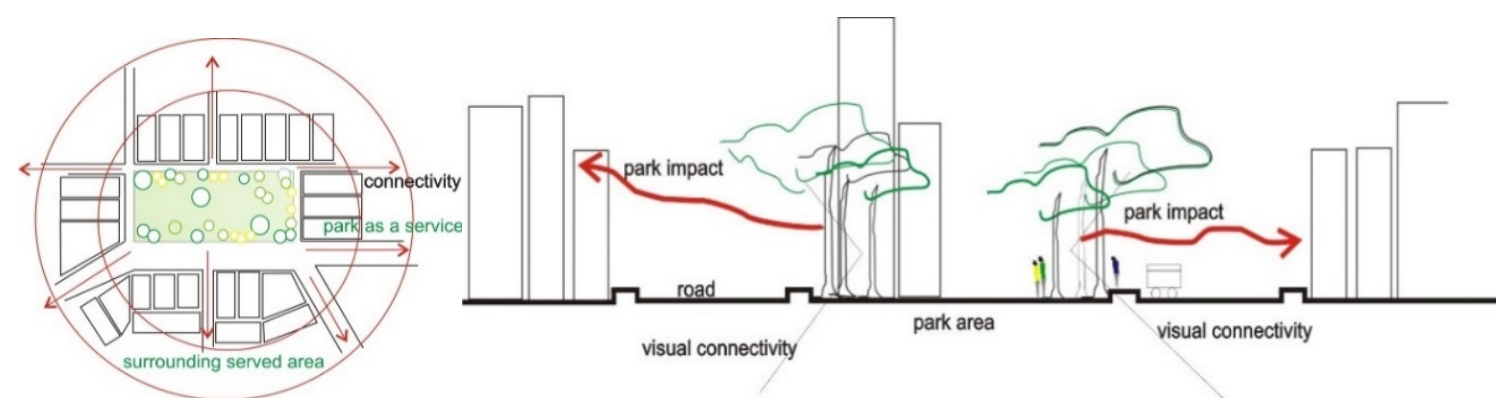

Figure 7: Street Layout at park surroundings to Improve the Connectivity [ both visual and physical] for Radiating Environmental Impact on Surrounding Areas

Therefore, it is confirmed that an integrated system of Small Parks with a proper layout can be more beneficial for such a dense built environment, like city of Dhaka. The lost lots, left over or forgotten spaces scattered throughout the city, can be developed as Small Urban Parks to improve the livability of dense cities. Therefore, people need to be aware of the importance of Small Parks in urban environments and designers must adjust their designs in order to create a better environmental performance for the people. In a nut shell, the research has directed the way to create quality Small Parks in residential areas of Urban Dhaka.

\section{SOURCES OF FUNDING}

This research received no specific grant from any funding agency in the public, commercial, or not-for-profit sectors. 


\section{CONFLICT OF INTEREST}

The author have declared that no competing interests exist.

\section{ACKNOWLEDGMENT}

This paper and the research behind it would not have been possible without the exceptional support of my supervisor, Professor and former Head, Dr. Qazi Azizul Mowla, Department of Architecture, Bangladesh University of Engineering and Technology, for the degree of Master of Architecture. His passion, knowledge and exacting attention to detail has been an inspiration and kept the work on track.

\section{REFERENCES}

[1] Ahmed. K.S. (1995) Approaches to Bioclimatic Urban Design for the Tropics with Spetial Reference to Dhaka, Bangladesh. A Thesis submitted in the partial fulfillment of the requirements for the Degree of Doctor of Philosophy, Environment and Energy Studies Programme, Architecture Association School of Architecture, London.

[2] Anisha, N.K., Mishima,N., Shoichi, K., Taguchi, Y. (2010), Assessment of Thermal Comfort in Respect to Building Height in a High Density City in the Tropics, American J. of Engineering and Applied Science, Vol 3, No. 3, 545551.

[3] Asaeda, T. and Then, V.U. (1998), Case study: Effects of Vegetation on the Climate in the Urban Area: In: Breuste, J. et al. (eds.) (1998): Urban ecology. Berlin et al.

[4] Barton,S. (2008), Human Benefits of Green Spaces, Adapted from the lecture "The Healing Garden: Social Research, PLSC100: Plants and Human Culture. November 18, 2008.

[5] Chang, C.R., Li, M. H. and Chang, S.D. (2007), A Preliminary Study on the Local Cool Island Intensity of Taipei City Parks. Landscape and Urban Planning 80, 386-95.

[6] Christiansen, M. L. (1941), Park Planning Handbook: Fundamentals of Physical Planning for Parks and Recreation areas, New York: Wiley \& Sons, Incorporated, John, c1977.

[7] DAP (2008), Preparation of Detailed Area Plan for Dhaka Metropolitan Development Plan (DMDP) Area, Draft Final Report submitted to RAJUK, September, 2008.

[8] DCC (2008), History of Dhaka City Corporation. DCC, Dhaka.

[9] Deelstra, T., Girardet, H. (2000), Urban Agriculture and Sustainable Cities, Thematic Paper 2: In: Proceedings of International Conference on 'Urban Agriculture and Sustainable Cities 43' Pp 43-65. Source: citeseerx.ist.psu.edu/viewdoc/download?doi=10.1.1.168

[10] Elmhurst Park District (1996), Parks and Recreation Standard, Elmhurst, Illinois. Source: http://www.elmhurst.org/Pwcode/commun.html.

[11] Emmanuel, R. (2005). Thermal Comfort Implications of Urbanization in a Warm-Humid City: The Colombo Metropolitan Region (CMR), Sri Lanka. Build. Environ 40: 1591-1601. DOI: 10.1016/J.BUILDENV.2004.12.004.

[12] Francis, C. (1997), People Places; Design Guidelines for Urban Open Space, Second Edition, John Wiley and Sons, Hoboken.

[13] Honjo, T., Narita, K., Mikami. T.,Sugawara, H., Kimura, K.,Kuwata, N.(2003), Observation of Cool Island Effect in Urban Park (Shinjuku Gyoen), Proceedings of ICUC-5,Lodx,Poland, vol 2, 261-264.

[14] Jorg,S., Paula,S., Erik,J., Denise,D. (2008), Simulation of the influence of Vegetation on Microclimate and Thermal Comfort in the city of Sa Paulo,Rev, SBAU, Piracicaba,Vol 3, No.2, June, 2008, 1-19.

[15] Lancaster, R. (1983), Recreation, Park and Open Space Standards and Guidelines, prepared by National $\begin{array}{llll}\text { Recreationand } & \text { Park } & \text { Association } & \text { Source: }\end{array}$ proceedings.esri.com/library/userconf/proc97/proc97/to500/.../p456.htm

[16] Lafortezza, R., Carrus, G., Sanesi, G., Davies, C. (2009), Benefits and Well-being Perceived by People Visiting Green Spaces in Periods of Heat Stress, Urban Forestry \& Urban Greening, Vol 8( 2), 2009, Elsevier,UK, 97108. 
[17] Marcus, C. and Francis, C. (1998), People Places: Design Guidelines for Urban Open Space, 2nd Edition, John Wiley \& Sons, Inc. Canada.

[18] Mirsch, N. (2011), Park Definitions \& Development Standards Part IV. City of Cottage Grove, Oregon. Source: www.cottagegrove.org/commdev/parksplan/Part\%20IV.pdf

[19] Mowla, Q. A. (2003), Towards a Paradigm of Livable City - the Case of Dhaka, The Jahangirnagar Review, Vol. XXVII, 43-54.

[20] Mowla, Q.A. (2005), Eco-design Concept in the Design and Management of Dhaka's Urban Open spaces, in XXII World Congress of Architecture, uia2005istanbul, Cities: Grand Bazaar of Architecture S, 3-7 July 2005 (subtheme: Urban Ecology)

[21] Muktadir.M.A.(2010), Designing Buildings in the Tropics with Environmental Technologies in Architecture, Ahsanullah University of Science and Technology, Dhaka, may 2010, pp,122.

[22] Quintas, A. V.E. and Curado, M. J. (2009), The Contribution of Urban Green Areas to the Quality of Life. City Futures'09, Madrid; June, 2010.

[23] Rahman, A. and Alam, M. (2005), Dhaka City State of Environment (SOE) 2005, UNEP in collaboration with BCAS \& DOE Bangladesh Centre for Advanced Studies, Dhaka.

[24] Tabassum.S.,(2018), Environmental Responses of Small Urban Parks in context of Dhaka City, in Journal of Physics: Conference Series, Volume 953, The 2nd International Joint Conference on Science and Technology (IJCST) 27-28 September 2017, Bali, Indonesia, 2018.

[25] Taha, H.., Akbari, H., Rosenfield, A. (1988), Vegetation Canopy Micro-climate: A field Project in Davis, California. Lawrence Berkeley Laboratory Report No. 24593. Lawrence Berkeley, Davis, California, USA.

[26] Upmanis, H., (2000), The Park has Its Own Climate, Swedish Building Research, No.2,

[27] Wong.N.H, Marcel.I. (2012), Comparison of STEVE and ENVI-met as Temperature Prediction Models for Singapore Context, International Journal of Sustainable buildings and urban development, vol 3(3), September, 2012, 197-209. 8-10.

[28] Yu, C., Hien, W. N. (2006), Thermal Benefits of City Parks. Energy and Buildings, Oxford, vol. 38, 105-120. 